tested and elaborated for the micro-chemical demonstration in cells and tissues of other elements, especially phosphorus, potassium, calcium and chlorine. He showed (Proc. Roy. Soc., B, 76, 217 ; 1905) that the colour reaction which tissues give under the influence of light when impregnated with nitrate of silver is not due, as had been supposed, to protein itself but to halogens, so that this staining method could be used for determining the distribution of chlorides in various cytological elements.

Being a keen student of the then rapidly expanding knowledge of physical chemistry, Macallum saw the possibility of using micro-chemical reactions to investigate the position in the cell of adsorbed ions and of thereby determining the extent to which this might be influenced by surface tension. Realising that the chloride reaction was independable for this purpose, because of slow penetration of the reagent, he devised a method by which potassium can be identified microchemically through its precipitation with hexanitrite of cobalt and sodium ( $J$. Physiol., 32, 95 ; 1905). He showed that when proper precautions are taken, the reagent penetrates the cell rapidly and that the position of the yellowish compound which it forms with potassium can be revealed by subsequent treatment with ammonium sulphide.

A thorough investigation, extending over several years, was then made of the distribution of potassium in plant and animal cells, and it was found that the element is concentrated in regions of the cell in a manner to suggest that alterations in surface tension are responsible. In a review of these researches published in 1911 in Ergebnisse der Physiologie, there is a full discussion of the hypothesis that the properties of division and movement in cells, as well as of secretion and absorption, can be attributed in part, at least, to surface tension phenomena. In a later discussion of his results (1913) (Presidential Address, Soc. of Biol. Chem.), Macallum advanced the view that the chief factor in muscular contraction "is the attraction between the molecules constituting the superficial film of a sarcostyle and forming an interface with the sarcoplasm surrounding the sarcostyle". This attraction, which is the cause of the surface tension, is not equal throughout the doubly refracting discs, as is shown by the fact that potassium salts are localised at the ends of the longitudinal axis, indicating, according to the Gibbs-Thomson principle, that the surface tension is lower here than on the lateral surfaces. During contraction, the discs tend to become spherical because the surface tension of the lateral surfaces becomes less. Speculations follow concerning the relationship of the breakdown of the lactic acid precursor to these changes in surface tension, and the paper is interesting reading in the light of the more recent researches in this field.

Macallum also made numerous observations by chemical methods of the percentage amounts of inorganic ions in the tissues and body fluids of various animals. He showed that when regard is paid to the relative proportions of sodium, potassium and calcium, rather than to the absolute concentrations of these ions, there is a striking resemblance between the composition of the ocean and the inorganic composition of the blood plasma of mammals. His first paper in this field appeared in 1903 (on "The Inorganic Composition of the Medusæ", J. Physiol., 29) and the conclusions there drawn are sustained in a second one published in 1910 ("The Inorganic Composition of the Blood of Vertebrates and Invertebrates and its Origin", Proc. Roy. Soc.) in which there is a discussion of the relationship of the development of the kidneys to the inorganic composition of the blood plasma of various marine invertebrates and vertebrates. In this paper Macallum points out that the establishment of a constant internal medium was the first step in the evolution of vertebrates from an invertebrate form and advances the view that the kidney was essentially the first typically vertebrate organ.

Throughout all his investigations, Macallum maintained a broad philosophical outlook and his thorough knowledge of biology and indeed of natural science in general enabled him to find various applications for the results of his laboratory investigations. As examples may be mentioned papers dealing with the origin of life on the globe (read before the Royal Canadian Institute about the year 1903) and the physical and chemical factors in heredity (address as president of the Biological Section of the Royal Society of Canada in 1910).

No account of Macallum's career would be complete that did not refer to his painstaking work from 1916 until 1921 as the first administrative chairman of the Advisory Council for Scientific and Industrial Research of Canada. His influence on the development of scientific research in the Dominion has been very great, partly through his active participation in the work of the Royal Canadian Institute and the Royal Society of Canada, and partly through his association first with the University of Toronto and latterly with that of McGill in Montreal.

Macallum was a man of imposing presence and forceful character, and it will be long before he is forgotten in Canadian scientific circles.

J.J.R. M.

\section{Dr. E. W. WASHBURN}

Dr. Edward Wight Washburn, who died on February 6 at the age of fifty-two years, was the chief of the Division of Chemistry of the U.S. Bureau of Standards at Washington. He was well-known to a wide circle as a physical chemist of distinction and the author of an "Introduction to the Principles of Physical Chemistry".

Washburn was a graduate of the Massachusetts Institute of Technology, where he was a pioneer in the study of the hydration of the ions in aqueous electrolytes. From 1908 until 1922 he held appointments in physical chemistry and then in ceramic 
engineering at the University of 1llinois, where he produced a long series of scientific and technical papers. Then, during a period of four years, he undertook the Herculean task of editing the "International Critical Tables", a task which was rendered supremely difficult by the fact that it had to be undertaken de novo instead of undergoing a progressive development. The completed tables, which have recently been made much more accessible and easy to use by the addition of a new index volume, will remain as a monument to Washburn's patience and skill, and are likely for many years to serve as a foundation, to which successive volumes of the "Annual Tables" may be added in order to maintain the up-to-date character of the whole edifice.

When appointed to the Bureau of Standards in 1926, Washburn undertook a wide programme of investigation and research, from which two items may be selected for comment. The first was the remarkable achievement of preparing crystals of rubber, by distillation under extreme conditions of low pressure and short distance, in which Washburn was keenly interested when I visited him at the Bureau of Standards in 1930. The second, which will perhaps be appreciated more widely than any other feature of his career, was his discovery in January 1931 of the fractionation of light and heavy water by the process of electrolysis. The separation of isotopes on a practical scale marks the beginning of a new period in chemistry, and, since Washburn's method of separation is already being developed as a manufacturing process, his name will long be remembered as the originator of this new period.

\section{T. M. LowRY.}

\section{Dr. L. R. FARNeLL}

WE regret to record the death of Dr. L. R. Farnell, formerly rector of Exeter College, Oxford, and the well-known authority on the religious cults of ancient Greece, which took place at Parkstone, Dorset, on March 28.

Lewis Richard Farnell attained the age of seventy-eight years on January 19 last, having been born at Salisbury in 1856. The second son of John Wilson Farnell, he was educated at the City of London School, of which Dr. Evelyn Abbott was then headmaster, and at Exeter College, Oxford, where he won an open classical scholarship. Practically the whole of the rest of his life was devoted to the service of his College and University. Two years after taking his degree in 1878, with first-class honours in both Classical Moderations and Literce Humaniores, he was elected to a fellowship of his College. He then studied classical archæology in Germany and travelled in Greece and Asia Minor, returning to Oxford to serve Exeter as tutor, sub-rector, senior tutor and dean, and from 1914 until 1928 as rector, in which office he succeeded the late Dr. W. W. Jackson.
His studies in classical archæology, more especially of the attributes of the gods as represented in art, led Farnell to the comparative study of Greek religious cults. He rapidly attained a high reputation as an interpreter of obscure passages in Greek literature in the light of his research. His greatest achievement, however, was his monumental work "The Cults of the Greek States" in five volumes, which appeared between 1896 and 1909, with a supplemental volume on hero cults, published in 1921. In this work Farnell showed a mastery of detail which was equal to, if it did not surpass that of the best German scholarship of the day, combined with an unusually wide knowledge of comparative material. His contribution to the study of Greek culture is original in conception, fundamental and epoch. making.

Farnell was also the author of a number of smaller works, dealing with the religions of Greece and the ancient East and with comparative religion, in which he showed a great gift of lucid, semi-popular exposition, combined with sound scholarship. He was a frequent and valued contributor to the learned periodicals concerned with his special studies.

In 1901 Farnell was one of the first to receive the newly instituted degree of D.Litt. of his University. He was University lecturer in classical archæology from 1905 until 1914, the first Wilde lecturer in natural and comparative religion, Hibbert lecturer in 1911, and Gifford lecturer in 1919. He served as Vice-Chancellor of the University in 1920-1923. If he required a high standard from his pupils in conduct, industry and scholarship, his whole life and work afforded them an admirable example.

Dr. AlbIN STocký, professor of archæology at Prague, died on April 18 at the age of fifty-eight years. He was the author of numerous publications dealing with Bohemia in the Stone and Bronze Ages. He had served on various archæological commissions and had given valuable assistance to museums in connexion with the identification of objects dating from prehistoric times.

WE regret to announce the following deaths :

Mr. Henry S. Hall, formerly head of the military and engineering side at Clifton College, author of many well-known textbooks of mathematics, on May 3, aged eighty-five years.

Mr. Carl Olaf Lundholm, technical adviser to the Nobel Trust in 1909-14, a pioneer in the manufacture of explosives, on May 8, aged eightyfour years.

Dr. J. P. van der Stok, director of the Section of Oceanography and Maritime Meteorology at the de Bilt Meteorological Institute, near Utrecht, in 1899-1923, formerly director of the Magnetic and Meteorological Observatory, Batavia, on March 29, aged eighty-three years. 